\title{
NATO Summit in Wales: From global megatrends to the new Euro-Atlanticism
}

\author{
Lidija Čehulić Vukadinović, Monika Begović
}

\section{Abstract}

Numerous representatives of theories of international relations, security theories or alliance theories have examined the new role of the North Atlantic Alliance or the North Atlantic Treaty Organization (NATO) in the post-bipolar world. Parallel with the theoretical examination of goals and tasks, NATO has transformed itself in practice, following the realities of the contemporary global era. In trying to achieve and keep the primacy of the strongest militarypolitical organization, the Alliance has - especially in the Strategic Concept adopted in Lisbon in 2010 - set the normative and institutional foundations of its global engagement, fulfilling the military (hard) and a wide array of non-military (soft) security challenges. This strategy has given rise to "Euro-Atlanticism", as a subsystem of international relations based on strong American-European relations, to fit with the process of regionalization of global politics. However, the 2013-2014 crisis in Ukraine has turned the focus of interest and activities of NATO once again primarily to Europe and it has stressed the importance and necessity of strengthening Euro-Atlantic security and defence ties. The most powerful member of the Alliance, the United States, is again strongly engaged in Europe and Russia, as a kind of 
(2) successor to the Soviet Union, is once more detected as a major threat to European security. There have been many aspects of theories of international relations that have tried to explain the dynamic of the post-Cold War international community. However, the approach based on neo-realistic assumptions of the role of a security community, collective defence and the use of military force has proved to be dominant. NATO will continue to work on its political dimension as an alliance of the democratic world and the September 2014 Wales Summit will certainly mark the return of NATO to its roots, strengthening its security and military dimensions in the collective defence of Europe from Russia.

\section{KEY WORDS:}

North Atlantic Treaty Organization (NATO), Euro-Atlanticism, Euro-Atlantic integration, Russia, military forces, crisis, collective defence, global security, neo-realism, security dilemma 


\section{Introduction}

The most fundamental challenges of the 21st century have been beyond the Euro-Atlantic area. When the Obama administration announced a new United States (US) defence strategy in early 2012, placing the security of Asia and the Middle East foremost, some European allies wondered whether the Euro-Atlantic partnership and NATO would still fit with future American defence objectives. Defence austerity in Europe has reached such depths that in his farewell remarks on 10 June 2011 in Brussels, the outgoing Secretary of Defence, Robert M. Gates, ' warned of a dim and dismal future for the Alliance.

To avoid this coming to pass, a group of experts (Burns, Wilson and Lightfoot 2012) from the Atlantic Council of the United States has recommended that NATO should:

1. create a Strategic Consultative Group to establish a longer term strategy for the Middle East, including the area from Syria to Pakistan and North Africa;

2. work with North African countries on issues concerning the role of the military in democracy;

3. focus on cyber security as a global issue and help organize the establishment of a Cyber Security Board, which could generate both military and critical infrastructure standards;

4. enhance its capabilities by expanding its special operations forces and undertaking an advanced research and development program. (Kramer 2012: 1-12)

\footnotetext{
"What I've sketched out is the real possibility for a dim, if not dismal future for the transatlantic Alliance. Such a future is possible but not inevitable. The good news is that the members of NATO - individually and collectively - have it well within their means to halt and reverse these trends, and instead produce a very different future", speech given by US Secretary of Defence Robert M. Gates on 10 June 2011: "The Security and Defense Agenda (Future for NATO)", Brussels, Belgium, US Department of Defense, http://www.defense.gov/ speeches/speech.aspx? speechid=1581. See, also, Burns, Wilson and Lightfoot (2012: 1), who state: "For the United States to achieve its international aims in a competitive and resource-constrained world, it needs a strong, capable and ambitious Europe as its leading partner".
} 
In fulfiling these tasks, the Euro-Atlantic allies would become effective and efficient in offering security and safety in globalized world. According to a report published in 2012 by the US National Intelligence Council (NIC), the transatlantic community is entering a new era in history with a number of global megatrends that will shape how the world looks by 2030. First, there is the rapid shift of economic and military power to Asia - Asia will have surpassed North America and Europe combined in terms of global power by 2030 (NIC 2012: iv). There is likely to be an accelerated diffusion of power to non-state actors (individuals and small groups), enabled by new lethal and disruptive technologies (NIC 2012: iv). In terms of technology, four arenas will shape global economic, social and military developments, as well as the world community's actions pertaining to the environment by 2030, namely: information technology, new manufacturing and automation technologies, technologies linked to the security of vital resources, and new health technologies (NIC 2012: ix-x). Changes in global demographics, together with rising scarcities of food, water and other natural resources, will increasingly trigger regional tensions and conflicts. Experts say that trends in the demographic picture suggest that over the next 15-20 years there will be an aging population, with a still-significant but shrinking number of youthful societies and states, migration will increasingly be a cross-border issue and there will be growing urbanization (NIC 2012: 20). Fifth, there is an ongoing energy revolution that is transforming geopolitics. Sixth, it is probable that the scope of regional instability will widen. In particular, the Middle East and South Asia are the two regions most likely to trigger broader instability. Finally, there is considerable uncertainty over the development of the leadership role for the US and the West. The US most likely will remain "first among equals" among the other great powers in 2030 because of its pre-eminence across a range of power dimensions and the legacies of its leadership role (NIC 2012: 98).

These global megatrends present a number of new, unprecedented challenges, but also opportunities for NATO at the strategic and operational levels. The process of transforming NATO to meet future challenges will be a long, uncertain and uneven endeavour. NATO should therefore adapt to these global megatrends in an era of global competition (Pavel and Nordenman 2013: 1-5). 
Some policy makers have argued that Europe embodies the past, whereas Asia, with the already strong Chinese economy, heralds the future. So, what should be the goal and point of NATO today? Despite the strategic rebalancing of the US in relation to Asia, President Obama has stressed more than once that the transatlantic community, led by NATO, still remains the greatest catalyst for global action. Therefore, NATO should continue to serve as a force for global security and stability. Nonetheless, many high officials within NATO hanker for the "good old days", when NATO was more focused on traditional collective defence (Article 5) and was protecting and defending Europe from the Soviet Union (Grosser 1980). NATO turned its attention back to Europe when the crisis in Ukraine/Crimea erupted in 2013-2014.

The crisis in Ukraine/Crimea has suddenly strengthened the perception of NATO members that Russia has returned to its role of an assertive regional power, seeking to secure its spheres of influence (former Soviet space) by military force. This perception means that the "true strategic partnership" between NATO and Russia (proclaimed by the NATO 2010 Strategic Concept, the Rome Declaration in 2002 and the Founding Act on Mutual Relations in 1997) must be redefined.

Shortly after the Crimea crisis started in 2014, NATO Secretary General Rasmussen stated that NATO would focus on protecting its members, that a strong and united NATO is needed in a changed world. As he put it, "NATO's core task is to protect and defend our Allies". Deterring potential Russian military aggression in Europe will become one of NATO's most important missions over the years ahead. Writing for the International Relations and Security Network (ISN), Richard Weitz (2014) stresses that "the ongoing crisis in Ukraine has provided NATO with fresh impetus and new challenges".

This paper does not primarily address predictions of how the relationship between NATO and Russia will develop, but rather analyses and suggests how the latest crisis in Ukraine could redirect NATO in various respects:

- It considers the successful implementation of stated objectives and programmes, which have created problems in the past (the 
smart defence concept, the issue of missile defence in Europe, reducing the gap in set-aside for defence between the US and European allies).

- It examines the perception of Russia as the main opponent (Economist 2014a: 19) with the aim of defining more clearly goals, priorities and the means of achieving them in contemporary international relations.

- It explores NATO's return to a focus on the Euro-Atlantic area, with Europe again becoming a geopolitical, geostrategic and geoeconomic area for confrontation between the West (led by NATO) and Russia.

- It looks at the implications of a renewed focus on Europe and the means of removing the fears of some European allies that NATO will no longer be led by the "old continent" but will instead follow the global strategy of the strongest ally in NATO - the US - and its strategy of a major political, economic and security step towards the Pacific.

Following this introduction, this paper consists two further sections and a conclusion. The first section analyses theoretical insights into the adjustments and survival of NATO as a model for securing postCold War international security. The following section shows how the strategy of the Alliance has changed and refers to the possible benefits of strengthening the transatlantic alliance as a consequence of the current crisis in Ukraine. The conclusion confirms the thesis stressed in this introduction, namely that the crisis in Ukraine will change NATORussian relations that were being built for so many years after the end of the Cold War, and therefore indicates the main directions of future Euro-Atlantic ties. 


\section{Theoretical insights into the role of NATO as a military and political alliance}

New opportunities in the international arena caused by the crisis in Ukraine and the position that Russia now holds in international relations have shown that the tendentious assertion that NATO has become obsolete as a military and as a political alliance on the international scene are without a basis in fact. Since the end of the Cold War and the demise of bipolar relations, which was followed by the creation of a New World Order, ${ }^{2}$ the North Atlantic Alliance has gone through specific political and institutional changes, rendering NATO not merely the opposing camp to the Warsaw Pact, but the foundation for a new means of ensuring international security. NATO has undergone several crises since the end of the Cold War, such as the collapse of the Soviet Union, the adaptation of NATO's collective defence remit to a changed international system, and now Russia returning to the scene of international politics.

NATO today is not merely a military-political alliance. NATO has implemented grand changes since 1989 and despite some theoretical suspicions concerning its survival, it celebrated its 65th anniversary in 2014. In a book entitled "NATO after Sixty Years", comprised of experts' essays, the challenges of adaptation and adjustment to post-Cold War security issues within and without its treaty-based responsibilities and competencies are described (Sperling and Papacosma 2012). NATO is positioned as a strong security actor in the international environment, in which the governments of allied countries respect the values of democracy, rule of law and individual liberty that underpin the Alliance.

Viewing NATO from the perspective of a transatlantic community and its relations with the European Union (EU), Stanley Sloan argues that NATO

2 The term "New World Order" was first used by the US President George Bush Sr. on 11 September 1990, when he spoke about the world order after the end of the Cold War and bipolar relations, one in which countries, that had previously been enemies would jointly defend democratic principles and the foundation of free society. It was a speech made with the purpose of justifying the US war in Iraq, but also with aim of promulgating a vision of all countries in the world living in peace and harmony. The full speech is available at: hitp://bushlibrary.tamu.edu/research/public_papers.php?id=2217\&year=1990\&month=9 (accessed 8 May 2014). 
$\Omega$ is a community of values shared by the Member States and cooperation in defense is an instrument to promote political change (Sloan 2005: 7). Sloan continues that NATO is not primarily designed to maintain peace among the member countries, but to protect those countries of the world around them. Therefore, although there were different political opinions within NATO when it came to enlarging it to encompass countries from the former Eastern bloc, extending its membership became a useful political move. This policy was caused by unrest in the southeast of Europe, the instability of new European countries and also the emergence of new threats (challenges of transnational terrorism, proliferation of weapons of mass destruction, cyber attacks, etc.), so that there was a need for a strong and broad alliance.

Representatives of neorealism, the most common political theory of the new era and the dominant school of thought on international relations, predicted that NATO would cease to exist after the collapse of the bipolar world, given that the reason for its creation and existence during bipolar relations - the Soviet Union - was history. ${ }^{3}$ (Waltz, 2000) As this collapse has not happened, the survival and sustainability of NATO in the new world order has in turn been justified by neorealists in terms of US unipolar hegemony.

Namely, the international system today is a combination of unipolar and multipolar factors, due to the fact that the US is the dominant superpower. Discussing the tactics of European countries in the 1990s, the following conclusion can be reached: Western European countries stayed in NATO to balance US forces and also former communist Eastern European countries, whereas Eastern European countries bandwagoned in joining NATO. ${ }^{4}$ Mowle and Sacko's (2008) article

3 On NATO's role in the New World Order and the reasons for its survival from the neorealistic perspective, see Waltz $(1993,2000)$. Waltz (2000) mentions that the fact that NATO survived the disappearance of the primary goal that it had when it was founded is one of the instances that shows why neorealists think that international institutions adjust to the needs of the states and their national interests. Therefore, NATO stops being an ordinary alliance, because if the transformation had never happened, the alliance would have no raison d'être without the opposite side. By adjusting to the national interests of the member states, it attracts new countries to become members and justifies its role as a transformed alliance.

4 On balancing and bandwagoning, see also: Schweller $(1988,1994)$. It is believed that the continuation of NATO is in the interests of the US and other member countries as it promotes global security stability. At the same time, NATO's defence planning creates the possibility of the US leading a coalition of states that want to cooperate because NATO has created an environment characterized by 50 years of peace in Europe. Both the US and EU admit NATO this role, especially in stating on the first page of the European Security Strategy (2003) that: "The United States has played a critical role in European integration and European 
begins with the sentence: "NATO staggers on, nearly 20 years after its original raison d'être withered away" (p. 597) as an introduction to offering reasons for NATO's survival and how countries position themselves according to new circumstances.

By means of such balancing, the Western European countries joined against the prevailing threat - at that time new threats in international relations and their own weaknesses. In a sense, the Eastern European countries, left on their own with weak positions in the New World Order, bandwagoned with NATO, allying themselves with the former source of danger, but at the same time joining the strongest alliance, which provided security protection through the North Atlantic Agreement.

Neorealists explain the persistence of NATO after the Cold War in terms of collective defence in combination with an internal dimension of the alliance by which the allies control each other. Viewed from the perspective of neorealism, it can be said that states join alliances to ensure the behaviour of other allies, advance the interests of their foreign policy and reduce the uncertainty of the international system, which neorealists define as international anarchy. ${ }^{5}$ Kenneth Waltz, a representative of neorealism or structural realism, discusses the reasons for NATO's survival after the end of the Cold War, viewed from the perspective that neorealists claimed that NATO would cease to exist if the international system were not characterized by the bipolar world. Waltz (2000: 5-41) argues that the changes the international system faced in the 1990s affected the ways in which states ensured their security. In the multipolar system, there was a growth in uncertainty, so

security, in particular through NATO". Also, on the other side, the US National Security Strategy from 2002 states: "There is little of lasting consequence that the United States can accomplish in the world without the sustained cooperation of its allies and friends in Canada and Europe". This could be the context for defining bandwagoning, which in some literature is explained as the total opposite of balancing - as supporting the stronger state or even a threat in some conflict - but it is not only that. Such a kind of bandwagoning would be more similar to a form of capitulation, which is not the best strategy. Bandwagoning is not a name for surrender, but rather joining the stronger coalition. States behave in line with bandwagon theory because they want to be on the stronger side. Thus, sometimes bandwagoning and balancing simply reflect each other, so it is not possible to prove conclusively which behaviour is the dominant one. For example, when Western European countries joined NATO, they balanced in relation to the Soviet Union and bandwagoned in relation to the US. Without the Soviet threat, NATO becomes a "tool" for bandwagoning. One form of bandwagoning is buckpassing: allowing the unipolar force to bear responsibility for some action from which everybody will benefit.

5 Anarchy is the basic concept of neorealistic theory. For more, see Waltz (1979, 1993), Mearsheimer (1990) and Glaser (1997). It is worth mentioning that neoliberal institutionalists stress the high level of interdependence among member states of the alliance, as well as the promotion of cooperation. 
(2) that international institutions such as NATO saw the opportunity to stress that their purpose lay in addressing issues of importance for international peace and security in a global context. Although neorealists do not believe in the importance of institutions, the survival of NATO shows how international institutions sometimes serve national goals.

Waltz (2000) continues to explain why NATO survived after losing its main purpose. The importance of the alliance has changed throughout history, so in the old multipolar world, before bipolar relations began to exist, only countries that had common characteristics, were very similar in size and would be completely dependent on each other joined forces. In the bipolar world, in which two alliances were formed, one force in each alliance provided security to its block of countries. Following this, however, NATO started to perform a completely new role. As the only remaining alliance, according to Waltz (2000: 5-41), it has also played the role of an extended arm of US foreign policy, guaranteeing the security of Western civilization. Looking at NATO purely as an alliance, Waltz believes that it is no longer only a contract that guarantees security as there is no answer to the question: assurance against whom? Although institutionalists claim otherwise, Waltz (1993: 44-79) argues that institutions, once they are founded, create reasons for their existence and start to behave as autonomous entities, independent of the will of their founders. Nonetheless, Waltz considers that this is not the case with NATO. Waltz explains why neorealists think NATO has lost its primary role. This happened after NATO became a means that the US has used to influence the foreign and security policies of European countries. The further spreading of NATO's influence actually demonstrates US power and not the strength of the alliance itself. The possibility of the US extending the life of NATO shows how international institutions are created by strong states to serve their interests. ${ }^{6}$ Waltz draws the conclusion that the prognosis of neorealists that NATO would disappear after the end of the Cold War is actually not wrong, nor was it based on erroneous assumptions or bad knowledge concerning international relations, but rather the view of US power was underestimated. Although NATO did make a big step in its transformation, Rynning (2005) also shares the view that NATO did not

6 That was visible through NATO especially during the US reaction in the conflicts in the Western Balkan countries. 
survive because it implemented major changes in its development, but because the US role was crucial. ${ }^{7}$

The reasons for NATO's survival as an international alliance could be examined through the views of Walt (2004), who claims that NATO must be sustained as it is beneficial for European and US interests. ${ }^{8}$ In his work "The Origin of Alliances" (Walt 1987), he expresses the opinion that nations do not form alliances only to create a balance of power. The most influential representative of theories of alliances, whose views can be implemented in today's world, Walt thinks that power is indeed important when creating an alliance because states ally with or against some power that represents the greatest threat. When entering an alliance, states may either balance (ally in opposition to the principal source of danger), or bandwagon (ally with the state that poses the major threat) (Walt 1985: 4). Balancing is alignment with the weaker side, whereas bandwagoning means choosing the stronger. Walt's (1985) conclusion is that the threat determines the choice of an ally, but also how long the alliance will last. The balance of threat theory is based on balancing behaviour and the proposition that states will join alliances in order to avoid domination by stronger powers. States join alliances to protect themselves from other states or coalitions whose superior resources could pose a threat (Walt 1985: 5). Walt thinks that alliances cease to exist when the threat is gone, further saying that states actually seek security against threats and not influence over other powers. This is the reason Walt offers for NATO initiating its transformation, its goal being to position itself strongly in the international order, taking the initiative to defuse the crisis in the southeast European region. In addition, the war in Kosovo confirmed European dependence on US military power projected through NATO.

For neorealists, states act according to their national interests in the anarchic international system, in which the security dilemma prevails. This shows a lack of trust in the intentions of other states. The rivalry between states is enhanced by the fact that when one state increases its power

7 See also Yost (1999).

8 For Walt's thoughts on alliances, see Walt (1985, 1997). 
(2) to be more secure, the fear of other states naturally grows. ${ }^{9}$ Neorealists view this competition and uncertainty in international politics as the cause of the need to achieve the highest possible security. According to the security dilemma theory, a state improves its defences to make it safer from potential attacks; the security dilemma arises when many of the means by which a state tries to increase its security decrease the security of others (Jervis 1978: 169). Thus, one state actually forces other states to work on their defence capabilities because of the fear of becoming weak. Thus, the safety of the states does not increase, but rather is reduced.

On the other hand, if a state becomes weak, it has no possibility of coercion. Having power in international politics means exactly having the possibility of coercion because states relate to each other primarily in terms of relative power and each is limited in the use of their power, primarily by opposing the power of others. The distribution of power among a small number of the most powerful states provides a basis for political decision making when considering on which side to stand or whether to be a member of a particular alliance (Waltz 1979: 112).

The security dilemma forces states to form an alliance or to strengthen an existing one. Glenn Snyder (1984) examines two reasons for the creation of an alliance under the conditions of a security dilemma. First, if states are not satisfied with their level of security, they will stream towards alliance formation to improve the existing security. Second, when states are unhappy with the level of cooperation they have with their existing allies, they may start the process of forming another alliance. To explain why states ally, we can use Snyder's articulation of the security dilemma, namely that even when no state has any desire to attack others, none can be sure that others' intentions are peaceful or will remain so; hence, each must accumulate power for defence purposes and it is easier to accumulate power as member of an alliance (Snyder 1984: 462).

9 On the security dilemma, see Jervis (1978), in which he explains two main arguments. The security dilemma is taken as the basis for examining the states' behaviour and it occurs when one state tries to increase its security in a way that decreases the security of other states (Jervis 1978: 169). See also Snyder (1990) and Glaser (1997). 
Christensen and Snyder (1990) $)^{10}$ consider two types of security dilemma when forming or joining an alliance: chain ganging and buck-passing. In the former, all the allies are equal and this leads to a high degree of interdependence within the alliance, so that each state is intertwined with the security of its alliance partners (Christensen and Snyder 1990: 138). Therefore, refusing to cooperate could disrupt the security of the alliance. Buck-passing illustrates a situation in which there is a threat, which causes states to join an alliance. In this case, a balance within the alliance is not immediately created because some states aim for membership at the expense of others. Their behaviour can be explained by the fact that they do not want to pay the price of entering a war, or they consider it preferable to remain out of a certain conflict. In view of the above, Waltz (1979: 140-141) considers that a bipolar system is safe because neither chain-ganging nor buck-passing dilemmas can arise in bipolarity. Today's conditions in the international system provide motives for cooperation within an alliance and the nature of the NATO alliance was formed based on the characteristics of this system.

Both theoretical foundations - neorealism and alliance theory - offer a logical approach to understanding the origins and character of policy in the transformation of NATO over the past 20 years. This approach very easily reflects NATO's position in relation to the Ukraine crisis as the only security guarantor. Neorealists claim that states behave in accordance with their national interests and the national interests of neighbouring countries, such as Ukraine, are lined to this. NATO is needed if such countries are to be safe from threat and the threat is again seen to be Russia. The fact is that NATO will exist as long as its member states face a threat to their national security, because alliances are primarily a means of ensuring national security.

The North Atlantic Alliance should again define the appropriate form of its international activities. The transition from the defensive role of the Alliance to the institution which is a means of crisis management, guaranteeing peace and security, has created a pressure on the allies to continue their activities by redefining security threats. From the

10 Chain ganging can be seen as an alliance in which the state enters an alliance with some other state because it guarantees its safety and security. In the case of buck-passing, a state joins an alliance in order to transfer the maintenance of the balance of power to the alliance and other member states. 
2 analytical perspective of contemporary international relations, Sean Kay, in his (1998) book "NATO and the Future of European Security", points out that regardless of the transformation and development of the EU, the European region still needs NATO as a force that imposes balance and stability in the region. However, Kay (1998: 3) also argues that "NATO's institutional tasks; organizational capacity; norms, principles, rules and procedures; and capacity for change have yet to have an independent impact on security in Europe".

Looking at the patterns of behaviour of NATO members, one can turn to Holsti, Hopmann and Sullivan (1973 cited in Bergsman 2001), who regard alliances as "a universal component of relations between political units, irrespective of time and place" (p. 2). They show that the behaviour of countries changes depending on threats and conclude that an increase in the level of threat increases cohesion within the alliance, which allows the alliance to respond to threats much more readily. This increase in cohesion is exactly what is currently happening within NATO and its member countries have shown their willingness to confront the new/old threat - Russia - which creates uncertainty and actually strengthens their connections and interdependence.

\section{NATO and the new reality}

Drawing on different theoretical explanations of the role of the alliance, NATO's survival after the collapse of bipolar international relations could be explained in terms of its gradual adjustment to changes and transformation in the global picture since 1989. It should be pointed out that the transformation of the Alliance (Summit Declarations, Strategic Concepts, other relevant documents) has been much easier and more successful than the realization of many goals that NATO has set itself. With the many problems that member countries had been facing in trying to make NATO a more efficient international military-political organization, it seemed that in the latest Strategic Concept adopted 
in Lisbon in 2010," NATO defined the main areas of its operations and future development for the next decade. The NATO Summit in Wales in September 2014 should have announced the transformation from the so-called operations phase into the post-operations phase. This is the year that marks 100 years since the beginning of the First World War, the 75th anniversary from the start of the Second World War, the 65th anniversary since the signing of the North Atlantic Treaty, 20 years of the Partnership for Peace (based on which almost all post-communist countries, that are not members of the Alliance - including Russia can cooperate with NATO, as can neutral nations, such as Austria and Switzerland) and the 10th anniversary of the so-called Big Bang - the second post-Cold War enlargement of NATO, when seven countries became NATO members. The close of 2014 will mark the end of the operation in Afghanistan, the largest, longest and definitely the most complex and most expensive peace mission in NATO history.

At the Wales Summit, it was foreseen that the heads of NATO would discuss three main aspects of the future of NATO:

1. implementing the operation Determined Support in Afghanistan after 2014 (training, assisting and advising Afghan forces and maintain some role in counter terrorism) (Piotrowski 2014);

2. finding modalities for strengthening NATO's capabilities (O'Reilly 2014) with the aim of implementing collective defence (Article 5) and crisis management;

3. defining relations and partnerships to secure cooperative security (Kramer 2013).

However, the Ukraine crisis has intervened and surprised by the Russian approach, the allies are having to set aside much of the planned agenda for the Wales Summit and concentrate not so much on the situation in Crimea and the crisis in Ukraine, but on Russia itself.

11 NATO Strategic Concept (2010) "Active Engagement, Modern Defence" [online] Available at: http://www. nato.int/cps/en/natolive/topics_82705.htm [accessed 7 May 2014] 
Relations between NATO and Russia have always had a special place in NATO's strategic decisions and in all post-Cold War transformations and adjustments to new global challenges. Although NATO's interests are different from those of Russia, NATO has managed to adjust its policies and find common ground. Aware that Russia has faced many problems on its path towards transition (Shevtsova 2007), as well as its desire to return to its former status of a strong country in the international arena (Bugajski 2004), NATO is cognisant that Russia, still a sizeable country, cannot be ignored nor isolated from global international order. Therefore NATO has founded numerous institutional forms of cooperation with Russia. ${ }^{12}$

However, relations between NATO and Russia have always been characterized by mutual suspicion (Stent 2014) and Clinton's strategic alliance with Russia of the early 1990s did not endure (Čehulić 2001: 93-101). Russian opposition to NATO enlargement in the former postSoviet area is a constant in Russian foreign policy strategy. Despite all the differences between them, diplomatic relations between NATO and Russia were for the first time endangered in 2008, after the Georgia crisis (Vukadinović 2008: 160-162). After the crisis and war in Georgia (2008), NATO-Russian relations improved somewhat, but after the crisis in Ukraine/Crimea, it seems highly unlikely that a new relationship of any warmth is going to emerge relatively soon. Rather, the Ukraine crisis offers a chance to the allies to define a new mission and strategy directly more clearly towards a familiar threat: Russia.

\section{Reforms of NATO capabilities}

Even before the global economic and financial crisis, the majority of NATO members were faced with radical cuts in their national defence budgets, yet had to finance (with less money) defence equipment which is costly and becoming costlier every year. For example, the unit cost of the Hunter fighter aircraft was GBP 4.6 million in 1995, compared

12 Russia is a member of the North Atlantic Cooperation Council (NACC), the Partnership for Peace (PFP) and Council 19+1. NATO and Russia have signed numerous agreements to fight global security challenges, based on which they participate in common activities. Until the Ukraine crisis (Crimea crisis), there was even a possibility of a joint construction of a missile shield in Europe. 
to its replacement, the Typhoon, which is superior to the Hunter in terms of capability and speed, but at a unit cost of GBP 72 million in 2012 (Davies et al. 2011).

NATO's Smart Defence proposal claims to do more with less money (Karnjuš 2013: 29-44), i.e. not spending more money but spending better. It is about specializing in what the Allies do best and seeking multinational solutions to common problems. It means pooling and sharing capabilities and it encourages NATO members to cooperate in developing military capabilities and coordinating efforts better (Blackwood 2012: 85-93). For Richard Weitz, (2014), the main features of Smart Defence include "aligning national capability priorities with those of NATO, promoting specialization by design rather than by default and pursuing cooperation in the development, acquisition, maintenance and operation of critical capabilities" (p. 3).

However, some NATO members, rather than sharing defence assets collectively, are still trying to have a full range of national military capabilities. Also, the concept of Smart Defence cannot ignore the incentives and constraints that operate in defence markets at both national and Alliance levels (Hartley 2012). However, now that Russia is again seen as an enemy, it will probably be much easier for NATO member states to coordinate their national defence plans and capabilities more closely to ensure that they have the critical capabilities needed for collective defence. Generally, it is argued that NATO would win any conventional war with Russia in Europe due to its superior technologies and human and financial resources. But in the last two decades, Vladimir Putin has increased Russia's national defence budget and has made sizeable investments in various R\&D defence programmes. Thus, advocates of NATO's Smart Defence concept now have a concrete reason to implement it better and faster.

The same goes for the US concept of Missile Defence in Europe. After two decades of debate and quarrelling, the Ukraine/Crimea crisis resulted in consensus among NATO members that missile defence would be a component of NATO's new forces. Furthermore, NATO has withdrawn its proposal of missile defence cooperation with Russia, which involved 
creating two joint centres to share early warning data and to plan and coordinate responses to a ballistic missile attack from a third country (O'Reilly 2014: 2).

Also, NATO members are aware that they have to increase their defence budgets to $2 \%$ of their national GDP, because now they face a potential threat from Russia in Europe. Once more, they have to prepare to protect their own homeland security. According to a recent report, published by the Stockholm International Peace Research Institute (SIPRI), military spending among most European NATO allies continues to be outstripped by Russia, China and other emerging powers (SIPRI 2013). A factor in this is that Europeans believe that they can enjoy security provided by the US without paying for it. Compared to its European allies, the US defence budget is vast at USD 600 billion in 2014, despite a drop in spending. Next year, the Pentagon's military budget is expected to fall to USD 498 billion, but it will still be around $35 \%$ of the global total (SIPRI 2013). ${ }^{13}$ Also, US troops have much more battle experience compared to their European allies.

\section{Russia as a major enemy of NATO and the new geostrategic conflicts for the former Soviet space in Europe}

The recent crisis in Crimea and then in other parts of east Ukraine is viewed at the Washington-based Center for Strategic and International Studies as one of the gravest European crises since the end of the Cold War. Jeffrey Mankoff (2014) writes this represents an escalation of the tactics that Moscow has used for the past two decades to maintain its influence across the domains of the former Soviet Union. Namely, the Kremlin has either directly supported or contributed to the emergence of four breakaway ethnic regions in Eurasia:

- Nagorno-Karabakh, a landlocked mountainous region in southwestern Azerbaijan that declared its independence under Armenian protection following a brutal civil war;

- Transnistria, a self-declared state in Moldova, on a strip of land

13 See also Economist (2013). 
between the Dniester River and Ukraine;

- Abkhazia, on Georgia's Black Sea coast;

- South Osetia, in northern Georgia. (Mankoff 2014: 60)

The main problem is that in that part of Eastern Europe and Eurasia, the New World Order (after the fall of bipolarism), has yet not settled. Geopolitically, geostrategically and geoeconomically, that region is still divided between the West (potential membership in NATO and the EU) and the Russian sphere of influence. A new European security architecture has to be created, but it is not an easy process. Some of these states have expressed their wish to join Euro-Atlantic and European structures (NATO, the EU), but some of them are still strongly politically and especially economically linked to Moscow. Both NATO and the EU have offered institutional ties of cooperation (NATO's "Partnership for Peace" programme and the EU's "Eastern Neighbouring" programme, Agreement of Association, etc.). At the same time, Russia views these countries (all of which were formerly part of the Soviet Union) as coming under the Russian sphere of influence (Lynch 2011: 110-118). Here, Moscow considers it has privileged interests, describing the former Soviet domains as Russia's "near abroad" immediately after the dissolution of the former Soviet Union (Trenin 2002: 150-170). Vladimir Putin has tried to enhance Russian influence in that part of Europe and Eurasia by pushing stronger political and economic integration with post-Soviet states, establishing first a Customs Union with Kazakhstan and Belarus and then trying to form a supranational Eurasian Union in an agreement initially signed by Kazakhstan, Belarus and Russia in May 2014 and due to come into force in January 2015, but intended also to Armenia, Kyrgyzstan, Ukraine and Tajikistan in 2015. This is supposed to encompass economic rather than political integration, through the formation of an economic bloc modelled on and rivalling the EU.

In this context, all frozen conflicts in post-Soviet countries and the latest crisis in Ukraine have to be seen as Russia's wish to slow down the process of integration of that part of the world into NATO and the EU. Moscow has stopped the enlargement of NATO a couple of times in recent history (the Baltic States, Georgia and Ukraine). In Russia, NATO is still 
( seen as an enemy, as a relic of the history of the Cold War. In its wish to resist the further enlargement of both NATO and the EU to include those countries which the Kremlin has traditionally seen as part of the Russian sphere of influence, Putin has deployed Russia's military forces in those regions. Abkhazia and South Ossetia each host approximately 3,500 Russian troops, together with 1,500 Federal Security Service personnel. Transnistria has some 1,500 Russian military solders on its territory and Armenia has approximately 5,000 Russian troops (Mankoff 2014: 67). All of these countries allow Russia to base troops on their territory. The Crimea peninsula already hosted Russia's Black Sea fleet and approximately 40,000 Russian troops are based on the Russia-Ukraine border. Six Russian Suhoi 27 fighter jets and three transport planes are deployed in Babrujsk in Belarus. The Belarusian President, Lukashenko, urged Moscow to deploy 10,000 Russian troops on Belarusian territory. At the time of writing, more than 3,500 Russian troops have taken part in tactical exercises on the Baltic coast near Kaliningrad close to Poland in the past few months (JutarnjiLIST 2014).

Russia, under Vladimir Putin, has been remarkably successful at frustrating NATO and Western projects on former Soviet territory. The Russian President, through his statements, has shown that Russia has actually got what it wanted (Economist 2014a). On the other side, since the start of the Ukraine/Crimea crisis, NATO has enhanced its deterrence and defence capabilities for its members neighbouring Russia. The allies have increased the number of surveillance flights over the Baltic countries and intelligence AWACS flights over Poland and Romania. Over 150 US troops are stationed in Poland and NATO has carried out a major military exercise in the Baltic territory, as well as enhancing the presence of allied naval forces in the Baltic, the Mediterranean and the Black Sea.

Scholars from the Polish Institute of International Affairs have suggested and even demanded that the current rotational presence of the US Air Force become a permanent deployment and that the Baltic States should supplement the Air Policing mission with permanent NATO land forces on their territories. The joint procurement by several Allies of air and missile defence units, with the aim of deploying them in the Baltic States, has been suggested as the basis for the establishment of regular 
exercises of NATO forces in the Baltic area over the next several years (Durkalec 2014: 2).

Of the former Soviet Republic, those of Russia's neighbours that are now NATO members (Lituania, Latvia and Estonia) are particularly concerned for their territorial integrity because they are difficult to defend. Their airspaces are entirely covered by Russian missiles, but even if Russia will not attack them militarily, Moscow can start to undermine them by stirring unrest among ethnic Russians there. An additional permanent presence of different NATO forces in countries neighbouring Russia should strengthen the message to Moscow that any eventual Russian act of military or non-military aggression against neighbouring NATO members would spark immediate engagement and a response from other NATO allies.

The large Russian military exercises held in 2009, which rehearsed an invasion of the Baltic States and included a simulated nuclear attack on Poland, shows how important the post-Soviet space is to Putin. In 2013, Russia and Belarus conducted another major exercise. The Kremlin has threatened preventive attacks on parts of the European missile defence system that America is deploying more than once. To reassure the nervous NATO member countries bordering Russia, the Alliance undertook its largest live-fire exercise in 2013, "Steadfast Jazz". Around 6,000 personnel from NATO countries and Ukraine, Finland and Sweden were involved in the manoeuvres in Poland and the Baltic States. NATO Secretary General Rasmussen said that "Steadfast Jazz was a signal to anyone who might have an intention to attack a NATO ally", adding "I do not expect Russia to have any intention to attack NATO allies, so you might say it is a signal to 'whom it may concern'" (Economist 2013: 55). Thus, the geopolitical rivalries with continental Europe, with NATO and Russia at its core, have stormed back to the central stage.

\section{NATO's return to a focus on Europe and the Article 5 clause}

While NATO has the military capacity to defeat Russian in a conventional armed conflict, the will to defend non-members is currently lacking. since the start of the crisis in Ukraine, there has been no consensus 
among all 28 NATO members to intervene militarily (Article 5) to defend the territorial integrity of Ukraine, Georgia, Moldova or other closely aligned states in the event of a Russian attack against them. It is more likely that Russia will use its military forces to protect and control its neighbouring space, which is vital to Russia's foreign policy interests. For NATO members this is not the case. Most Americans say that defending the security of allies is very important, but only $6 \%$ would use force over Ukraine (Economist 2014b).

It is certain that NATO will not (soon) change Article 5 on collective defence, so an armed attack on any member will be considered an attack on all member countries. The US, as a member of the Alliance, is committed to protecting its Europeans allies. However, today the US is globally overstretched and acting as global peacekeeper and Europeans are mindful of the limits of US power. A survey by the Pew Research Centre shows that $52 \%$ of Americans want the US to "mind its own business internationally" (Economist 2014c: 9); this is the largest figure in five decades of polling on this theme. During his last visit to the Pacific region (Spring 2014), President Obama offered fresh guarantees that the defence treaty between Japan and the US covers all Japanese administrative territory, including the Senkaku islands, which China also claims. In the Philippines, he has signed a new 10-year agreement to give US forces greater access to local bases and the US has approximately 28,000 troops stationed in South Korea. There are some 30,000 US forces based in the whole of Europe today, compared to 213,000 in 1989.

Europe's privileged status in US foreign policy is a Cold War anachronism. Today, in a so-called post-European world (Haass 2013: 38-42) development in the Asia-Pacific region is influencing US defence priorities. In contrast, the development of the situation in Asia does not exert a major influence on European defence priorities and not all Europeans are committed to US global strategy. Since the end of the Cold War, Europeans have been afraid that the US might forget them; however, now, with the crisis in Ukraine/Crimea, they have a concrete reason to call the Americans back. 
Regardless of further events in and around Ukraine, Euro-Atlanticism, based on US-European relations and their joint action against an external enemy, again has the opportunity to show its strength in the European arena (Bugajski and Teleki 2007).

\section{Strategic opportunities for NATO's open-door policy and global partnerships}

By consolidating and strengthening Euro-Atlantic ties for the defence of Europe, NATO now has the opportunity to enhance its open-door policy. Rather than become engaged in major military conflict, NATO aims to strengthen its relations with Georgia, Azerbaijan and perhaps one day with Ukraine and other post-Soviet countries, if and when they show an interest in a closer relationship with NATO. Georgia could be admitted into the Membership Action Plan for NATO at the Wales Summit (having missed the opportunity in 2008 because of the war). Furthermore, Monte Negro could receive an invitation to become a member country. Although the Wales Summit was not foreseen as a forum for enlargement, the new geostrategic Russian position means that the Summit will be oriented towards new partners and allies. Furthermore, the enlargement policy of NATO is one of the most successful policies of the Alliance, although its role in NATO's transformation is not stressed enough. NATO today is a rare international organization (the only military political one), being one in which membership countries still show their interest. At a time in which NATO is seeking more optimal ways to redefine relations with Russia, NATO can offer something more than Moscow, namely Euro-Atlantic partnership. The enlargement of NATO could be a bargaining chip in relation to Russia, because NATO would be able to consider possible new members according to their relationship with Russia. 


\section{Conclusion}

NATO should use the 2014 Wales Summit to emphasize the abovementioned problems. As Mead (2014) notes, "...Westerners should never have expected old-fashioned geopolitics to go away. They did so only because they fundamentally misread what the collapse of the Soviet Union meant: the ideological triumph of liberal capitalist democracy over communism, not the obsolescence of hard power" (p. 68). Some Western scholars find current trends disturbing as in international relations and international politics following the end of Cold War soft power became smart power (Nye 2011). Thus, both NATO experts and NATO members have focused on a global world order based on democracy, liberalism, the role of law, global governance, human rights, climate change, energy sufficiency, the fight against terrorism, cyber security, and so on. However, hard power issues in terms of security and oldfashioned geopolitics have not disappeared from international politics. One might argue that this is good for NATO because, despite all the transformations undergone in the last two and a half decades, it is still a military alliance; as such, it is much easier to organize its structure, goals and forces when the enemy is visible and clearly defined. Seen in this light, the latest and most significant deterioration in NATO-Russian relations provides advantages for NATO.

The need for a deep revision in relations with Russia and the new European security landscape should be key features for NATO at the Wales Summit in September this year. Re-building geopolitical and geostrategic stability and predictability in wider Europe is again the focus and the main task of NATO, which is the largest, strongest, richest and most advanced military-political Euro-Atlantic organization. The crisis in Ukraine has had the unintended consequence of giving NATO a renewed sense of purpose. It is believed that the borders of NATO countries are red lines, so that Russia will not undertake a military attack on any NATO members.

Instead of a Third World War or a NATO-Russian War, the West, led by the US, has imposed financial and economic sanctions on Russia, 
including visa restrictions, travel bans and asset freezes for a number of wealthy Russian people. The US has shown considerable enthusiasm for such an approach toward Moscow, 14 followed by the European members of NATO, especially those who have in the past developed different kinds of economic cooperation with Russia or are dependent on Russia's energy supply.

Until the Ukraine crisis, NATO was trying to transform itself into a global security alliance. Now again its focus of interest has become local: Europe/Russia. It is precisely because NATO has proved to be so amenable to and flexible in changes in the decades since 1989 that it has remained attractive for new member countries which would like to join the Alliance.

14 The Chairman of the Senate Armed Services Committee, Democrat Senator Carl Levin, on his visit to Ukraine on 25 April 2014 called for harsher sanctions on Russian banks and energy interests. The leading Republican on the Senate Foreign Relations Committee, Bob Corker, has said that the Russian stockmarket actually rose after the latest US sanctions were announced, suggesting that the sanctions imposed were weaker than the world expected (Economist 2014: 9). 


\section{Bibliography}

A Secure Europe in a Better World - European Security Strategy, Brussels,

12 December 2003. Available at: http://www.consilium.europa. eu/vedocs/cmsUpload/78367.pdf (accessed 8 May 2014).

Bergsman, S., 2001. The concept of military alliance. In: Reiter E. and Gaertner, H. eds. Small States and Alliances. Heidelberg, New York: Physica Verlag.

Blackwood, M., 2012. How smart is smart defense? A review of NATO's smart defense proposals connections. The Quarterly Journal, $11(3): 85-93$.

Bugajski, J., 2004. Cold Peace. Russia's New Imperialism. Washington DC: CSIS.

Bugajski, J. and Teleki, I., 2007. Atlantic Bridges. America's New European Allies. Lanham: Rowman and Littlefield.

Burns, R. N., Wilson, D. M. and Lightfoot, J., 2012. Anchoring the Alliance. Washinton DC: The Atlantic Council of the United States.

Christensen, T. J. and Snyder, J., 1990. Chain gangs and passed bucks: Predicting alliance patterns in multipolarity. International Organization, 44(2): 137-168.

Čehulić, L., 2001. Clinton inovi svjetski poredak. Zagreb: Politička kultura.

Davies, N., Eager, A., Maier, M. and Penfold, L., 2011 . Intergenerational Equipment Cost Escalation, DASA-DESA, Economic Working Paper, No 1. London: UK Ministry of Defence.

Doorstep statement by NATO Secretary General Anders Fogh Rasmussen, 16 April 2014. Available at: http://www.nato.int/cps/ en/natolive/opinions_109231.htm (accessed: 15 May 2014).

Durkalec, J., 2014. NATO Policy towards Russia after the Crimea Annexation: More Deterrence and Farewell to Partnership, Bulletin, 634(39). Warsaw: The Polish Institute for International Affairs. 
Economist, 2013. NATO's future: Back to basics, Drawsku Pomorskie, Poland, 16 November, pp. 55 (also available online: http:// www.economist.com/news/international/21589900-atlanticalliance-wants-new-role-after-afghanistan-time-being-it-looking (accessed 10 May 2014).

Economist, 2014a. Putin's gambit, 10 May, pp.19 (also available online: http://www.economist.com/news/europe/21601899-russianpresidents-unexpected-concessions-ukraine-reflect-fact-hehas-already-got (accessed 18 May 2014).

Economist, 2014b. The decline of deterrence, 23 May, p.37 (also available online: http://www.economist.com/news/unitedstates/21601538-america-no-longer-alarming-its-foes-orreassuring-its-friends-decline (accessed 30 May 2014).

Economist, 2014c. What would America fight for? 3 May, pp.9 (also available online: http://www.economist.com/news/ leaders/21601508-nagging-doubt-eating-away-world-orderandsuperpower-largely-ignoring-it-what (accessed 15 May 2014).

Glaser, C. L., 1997. Security dilemma revisited. World Politics, October: $171-201$.

Grosser, A., 1980. The Western Alliance. European-American Relations since 1945. New York: The Continuum Publishing Corporation.

Gullestad, J. R., 2013. US Rebalancing: A View from Europe. Washington DC: Brent Scowcroft Center on International Security, Norwegian Institute for Defence Studies.

Haass, Richard. N., 2013. Foreign Policy Begins at Home. New York: Basic Books.

Hartley, K., 2012. White Elephants? The Political Economy of Multi-National Defense Projects. Brussels: Foundation for European Reform.

Jervis, R., 1978. Cooperation under the security dilemma. World Politics, 30(2): 167-214.

JutarnjiLIST, 2014. Bjelorusi u strahu od Rusije, HINA, 22 April, http://www. jutarnji.hr/bjelorusi-u-strahu-od-rusije--moramo-nezavisnost-nase- 
zemlje-braniti-svim-sredstvima-/1185400/ (accessed 10 May 2014).

Karnjuš, I., 2013. Smart defense - Is it really something new for NATO? In: Čehulic Vukadinović, L. ed. YEARBOOK 2012, 10(1): 29-44.

Kay, S., 1998. NATO and the Future of European Security. New York: Rowman and Littlefield.

Kramer, F. D., 2012. Transatlantic Nations and Global Security: Pivoting and Partnerships. Washington DC: The Atlantic Council of the United States.

Kramer, F. D., 2013. NATO Global Partnerships: Strategic Opportunities and Imperatives in a Globalized World. Washington DC: The Atlantic Council of the United States.

Lynch, A. C., 2011. Vladimir Putin and Russian Statecraft. Washington DC: Potomac Books.

Mankoff, J., 2014. Russia's latest land grab. How Putin won Crimea and lost Ukraine. Foreign Affairs, 93(3), 60-68.

Mead, W. R., 2014. The return of geopolitics. The revenge of the revisionist powers. Foreign Affairs, 93(3): 69-79.

Mearsheimer, J., 1990. Back to the future, instability in Europe after the Cold War. International Security, 15(1): 5-56.

Mowle, T. S. and Sacko, D.H., 2008. Global NATO: Bandwagoning in a Unipolar World. Contemporary Security Policy.

NIC, 2012. US National Intelligence Council in its Report Global Trends 2030: Alternative Worlds, 2012, Washington. Available at http://www.dni.gov/files/documents/GlobalTrends_2030.pdf (accessed 10 May 2014).

Nye, Jr., J. S., 2011. The Future of Power. New York: Public Affairs.

O'Reilly, P., 2014. Ten Ideas for SmarterNATO Missile Defense. Washington DC: Brent Scowcroft Center on International Relations.

Pavel, B. and Nordenman, M., 2013. Global Trends and the Future of NATO: Alliance Security in an Era of Global Competition. 
Washington DC: Brent Scowcroft Center on International Security, Norwegian Institute for Defence Studies.

Rynning, S., 2005. NATO Renewed: The Power and Purpose of Translatlantic Cooperation. New York: Palgrave Macmillan.

Schweller, R. L., 1988. Deadly Imbalances: Tripolarity and Hitler's Strategy of World Conquest. New York: Columbia, University Press.

Schweller, R. L., 1994. Bandwagoning for profit: Bringing the revisionist state back in. International Security, 19(1): 72-107.

SIPRI, 2013. Trends in World Military Expenditure, 2012, April 2013, SIPRI Fact Sheet. Available at: http://books.sipri.org/files/FS/ SIPRIFS 1304.pdf (accessed 5 May 2014).

Shevtsova, L., 2007. Russia Lost in Transition. The Yeltsin and Putin Legacies. Washington DC: Carnegie Endowment.

Sloan, S. 2005., NATO, the European Union and the Atlantic Community: The Transatlantic Bargain Challenged. Lanham: Rowman and Littlefield.

Snyder, G. H., 1984. The security dilemma in alliance politics. World Politics, 36(4); 461-495.

Snyder, G. H., 1990. Alliance theory: A neorealist first cut. Journal of International Affairs, 44(1): 103-123.

Snyder, G. H., 1997. Alliance Politics. Ithaca, New York: Cornell University Press.

Speech by former American President George Bush Sr. Available at: $\quad$ http://bushlibrary.tamu.edu/research/public_papers. php?id=2217\&year=1990\&month=9 (accessed 8 May 2014).

Sperling, J. and Papacosma, S.V., 2012. NATO after Sixty Years - A Stable Crisis. Kent, Ohio: The Kent State University Press.

Sten, R., 2005. NATO Renewed: The Power and Purpose of Translatlantic Cooperation. New York : Palgrave Macmillan.

Stent, A. E., 2014. The Limits of Partnership. US-Russia relations in the Twenty-First Century. Princeton: Princeton University Press. 
( Strategic Concept 2010. Active Engagement, Modern Defence. Available at: http://www.nato.int/cps/en/natolive/topics_82705. htm (accessed 8 May 2014).

The National Security Strategy of the United States of America, September 2002. Available at: http://www.state.gov/ documents/organization/63562.pdf (accessed 8 May 2014).

Trenin, D., 2002. The End of Eurasia. Russia on the Border between Geopolitics and Globalization. Washington DC: Carnegie Endowment for International Peace.

Walt, S. M., 1985. Alliance formation and the balance of world power. International Security, 9(4): 3-43.

Walt, S. M., 1997. The Origin of Alliances. Ithaca: Cornell University Press.

Walt, S. M., 2004. The imbalance of power - On the prospects for effective American-European relations, March-April 2004, Harvard Magazine. Available at: http://harvardmagazine.com/2004/03/ the-imbalance-of-power.html (accessed 10 May 2014).

Waltz, K. N., 1979. Theory of International Politics. Reading MA: AddisonWesley.

Waltz, K. N., 1993. The emerging structure of international politics. International Security, 18(2): 44-79.

Waltz, K. N., 2000. Structural realism after the Cold War. International Security, 25(1): 5-41.

Weitz, R., 2014. NATO on Edge, ISN - International Relations and Security Network, Zurich. Available at: http://www.isn.ethz.ch/DigitalLibrary/Articles/Detail/?id=178926 (accessed 15 May 2014).

Yost, D., 1999. NATO Transformed: The Alliance's New Roles in International Security. Washington DC: US Institute of Peace Press. 
Monika Begović (monika.begovic@gmail.com) gained a Master of Science degree in International Relations at the Faculty of Political Science of the University of Zagreb. She is active in research of different aspects of transatlantic relations, NATO's relations with the EU, especially in regards with the EU's Common Foreign and Security Policy. At the same Faculty, Begović graduated in journalism and later worked as a journalist in various media, and as a permanent journalist at the daily newspaper Slobodna Dalmacija, Office in Zagreb. For twelve years Begović has worked for the United Nations, where she specialized in running projects, and is currently a project manager and consultant on an EU twinning project.

Lidija Čehulić Vukadinović (radovanvukadinovic@yahoo. com) is a professor of International Relations, International Organizations and Euroatlantic organizations at the Faculty of Political Science of the University of Zagreb. Čehulić published numerous books and articles, has worked as editor of scientific publications and has participated in different scientific conferences and seminars in Croatia and abroad. Čehulić is also active in the non-governmental sector and is a board or regular member of several associations, such as: the Atlantic Council of Croatia, the Centre for International Studies, the Croatian Association for International Studies and the International Studies Association (ISA). 